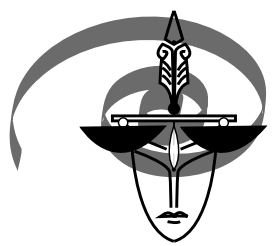

EUROPEAN

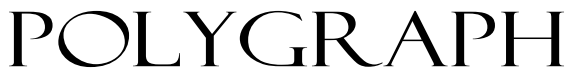

Volume $11 \cdot 2017 \cdot$ Number 2 (40)

DOI: 10.1515/ep-2017-0011

\title{
Report from the International \\ Conference on Polygraph Examination in Central and Eastern Europe after 1990, Krakow, Poland. 12-13 June 2017
}

Instrumental lie detection with the use of a polygraph has been relatively well investigated in both scientific and practical terms. Even recently a monographic work devoted to the history of the polygraph examination has been published in Poland (see Widacki 2017), which demonstrates that the issue has a tradition, and the polygraph and its potential use are not phenomena lying "on no man's land". Yet the practical use of polygraph examinations in various countries, and especially in Central and Eastern Europe, has not received sufficiently broad recognition on an international scale. That is why the organisation of various meetings devoted to such issues should be commended.

Without running into the jeopardy of serious charges, one can assume that the conference organised recently by the Department of Criminology, Criminalistics, and Police Science of the Faculty of Law, Administration, and International Relations was one of Poland's first conferences devoted to applied polygraph examination in selected countries of Central and Eastern Europe. Just for this one reason, the initiative should deserves praise. The event was international in its nature, and the participants represented nine countries: Ukraine, Azerbaijan, Kazakhstan, Russia, Lithuania, Belarus, the US, Slovakia, and Poland. They were primarily scientific experts and 
polygraph examiners, including members of the Ukrainian Polygraph Association, American Polygraph Association and the Polskie Towarzystwo Badan Poligraficznych (Polish Society of Polygraph Examination). Moreover, the guests included officers of Polish and foreign police and other uniformed forces.

The meeting followed the typical conference pattern, and the sessions arranged over two days were held in four content sections concerning The Legal Status of Polygraph Examination, Polygraph Examination in Criminal Cases, Polygraph Examination in Private Business, and Scientific Research in Polygraph Examination. The languages of the conference were Russian and Polish.

The conference was opened by the Rector of the Andrzej Frycz Modrzewski Kraków University (KAAFM), Professor Jerzy Malec, who emphasised the role and significance of such meetings for the development of science and exchange of experience. The keynote speaker was the Dean of the Faculty of Law, Administration, and International Relations, Professor Jan Widacki, who pointed to the reasons for organisation of the conference. Explaining the main theme of the meeting, he explained that polygraph examinations became highly popular in many countries of the former USSR, as well as in many countries of Central and Eastern Europe after 1989. This was connected with the introduction of acts of law that regulated the operation of police and other uniformed services, and legislation on polygraph examinations in recruitment purposes. Moreover, the market of private services in instrumental detection of deception opened at the time. Furthermore, the legal status of polygraph examinations in the criminal trial changed from inadmissibility of the use of results of polygraph examinations as evidence to the acceptability of the polygraph both for screening and evidence.

Presided over by Jan Widacki and Sergei Aleskovskyi (Kazakhstan), the first session began with an address by Bakhtiyar Aliyev (Azerbaijan), who reported on the use of polygraph examinations in the Republic of Azerbaijan. The speaker presented types and areas where polygraph is routinely applied. The following paper concerned the history of polygraph examinations in Kazakhstan. Sergei Aleskovskyi pointed to the Polish contribution to the area, consisting in the academic achievements of Zienkiewicz (?). The analysis of practical application of the polygraph in the Republic of Belarus was presented by Kristina Knazeva (Belarus). The following presentation concerned the legal regulation of polygraph testing in the Republic of Belarus. Vitaliy Shapovalov from Belarus discussed in detail the current legislation regulating field. The next speaker was Aleksandr Motlach from Ukraine who presented how science has contributed to the endorsement of polygraph in Ukraine. The first session closed in a paper by Ihor Usikov (Ukraine) concerning practical use of polygraph for psychophysiological forensic expertise in Ukraine. 
Devoted to polygraph examinations in Poland, the following session, was chaired by Milan Kormos (Slovakia) and Ihor Usikov, and opened with a paper by Ewa Plebanek (Poland), concerning the Polish procedures for the use of polygraph in criminal trials from the perspective of current jurisprudence and judgements. Subsequently, Marcin Gołaszewski (Poland) and Anna Szuba-Boroń (Poland) discussed the legal and practical aspects of polygraph examinations of civil servants in Poland. The following presentation was devoted to a fairly controversial issue concerning the legal status of polygraph examinations in labour law. Kinga Piwowarska expressed the opinion that currently binding regulations do not allow polygraph examinations at the stage of recruitment, as - in the speaker's opinion - the principle of "what is not forbidden is permitted" does not apply to private employers.

The third session, presided over by Marcin Gołaszewski and Vladimir Knazev (Belarus), began with a paper by Oksana Stevenson and Bruce White from the US. Representing Axciton Systems Inc. the speakers discussed the process of interpretation of difficult polygrams by analysing individual polygraph channels. The following case-study type presentation concerned investigations into murders perpetrated in Ukraine in the past. Oleh Rybalchenko (Ukraine) presented his two proprietary polygraph tests were to provide a solution for such cases. The following paper was delivered by Vitas Saldziunas from Lithuania, who described the practice of applying Utah Probable Comparison Test and discussed the use of the technique in Lithuania. The last paper in the session was presented by Oleh Rybalchenko and concerned the use of the GSR channel for effective demonstration of deliberate distortions of the polygraph examination.

The last, fourth session was chaired by Bakhtiyar Aliyev and Vitaliy Shapovalov. Viktoriya Larina (Russia) discussed details of the training for professional polygraphers at ANO DPO "CPP”. Later, Olga Aleskovskaia (Kazakhstan) interestingly discussed the methods and advantages from profiling for polygraphers. The subsequent speaker, Vladimir Knazev from Belarus presented the methodological aspects of polygraph examinations of law enforcement structures in the Republic of Belarus. Then Milan Kormos pointed to the potential use of the polygraph for staffing purposes at the Ministry of the Interior of the Republic of Slovakia. The last paper was presented by Vitaliy Kirvel from Belarus who discussed the practice of performing psychophysiological expertise with the use of polygraph in examining criminal cases concerning sexual liberty and physical integrity of minors in the Republic of Belarus. The conference was rounded up by Jan Widacki.

The conference, and especially its content and organisation, must be highly commended. Its international character made it possible to exchange information and experience concerning the application of polygraph examinations in Central and 
Eastern Europe. Professional polygraphers had an opportunity to compare the range of use of the instrument in a number of countries in three areas, namely, criminal cases, private practice, and examinations conducted for police, law enforcement and other uniformed services. Moreover, the substantial issues presented at the conference included the descriptions of legal regulations of the status of polygraph examinations in various jurisdictions. It must be noted that the use of polygraph in the countries represented by conference participants is highly popular, and the private polygraph market is well developed. One can only hope that appropriate control mechanisms will be implemented to support the quality of the services provided by poligraphers of various nationalities, and that the organisers arrange a similar meeting in near future.

\section{References}

Widacki J. (2017), Historia badań poligraficznych, Oficyna Wydawnicza AFM, Kraków. 